\title{
Leuconostoc miyukkimchii sp. nov., isolated from brown algae (Undaria pinnatifida) kimchi
}

\author{
Correspondence \\ Che Ok Jeon \\ cojeon@cau.ac.kr
}

\author{
Seung Hyeon Lee, Moon Su Park, Ji Young Jung and Che Ok Jeon
}

Schools of Biological Sciences \& Research Center for Biomolecules and Biosystems, Chung-Ang University, Seoul, 156-756, Republic of Korea
Kimchi is a traditional food, emblematic of Korean culture, that is fermented from vegetables such as Chinese cabbage and radish. In recent years, kimchi's health-promoting characteristics have been recognized continually and kimchi is known as one of the world's five healthiest foods (Song, 2004). Fermentated vegetables in kimchi are usually processed with various seasoning ingredients such as red pepper powder, garlic, ginger and salts at low temperatures and lactic acid bacteria such as those of the genera Leuconostoc, Lactobacillus, Streptococcus, Pediococcus and Lactococcus play an important role in kimchi fermentation and resulting taste (Cheigh et al., 1994; Mheen \& Kwon, 1984; So \& Kim, 1995; Lee et al., 1997; Jung et al., 2011). Generally, different kinds of kimchi are classified based on the main raw materials (vegetables) and there are many kinds of kimchi in several regional provinces of Korea. Many lactic acid bacteria have been isolated from Korean kimchi (Kim et al., 2000, 2003; Yoon et al., 2000; Choi et al.,

The GenBank/EMBL/DDBJ accession numbers for the $16 \mathrm{~S}$ rRNA and recA gene sequences of strain $\mathrm{M}^{\top}{ }^{\top}$ are HQ263024 and JF261009, respectively. The accession number for the recA gene sequence of $L$. inhae KCTC $3774^{\top}$ is JF261010.

Two supplementary figures are available with the online version of this paper.
2002; Lee et al., 2002). The genus Leuconostoc encompasses a phylogenetically coherent group of lactic acid bacteria that are Gram-positive, facultatively anaerobic, asporogenous, catalase-negative, spherical organisms containing genomic DNA with relatively low G $+\mathrm{C}$ content (3645 mol\%) (Chambel et al., 2006; De Bruyne et al., 2007; Ehrmann et al., 2009). In the course of a study on kimchi microbiota, a novel bacterium belonging to the genus Leuconostoc was isolated from brown algae kimchi and its phylogenetic position was investigated using a polyphasic approach.

Strain $\mathrm{M} 2^{\mathrm{T}}$ was isolated from fermented miyukkimchi made of a brown algae (Undaria pinnatifida), which is a regional kimchi in Korea. Isolation and identification of bacteria from the brown algae kimchi (miyukkimchi) were performed as described by Kim et al. (2008). Briefly, miyukkimchi was fermented for 20 days at $4{ }^{\circ} \mathrm{C}$ and then a small amount of kimchi soup was serially diluted in $0.9 \%$ (w/v) saline, spread on MRS (Difco) agar plates and incubated at $25{ }^{\circ} \mathrm{C}$ for 3 days. Colonies grown on MRS agar were resuspended in $100 \mu \mathrm{l} \%$ (w/v) Chelex-100 solution (Bio-Rad) and boiled for $10 \mathrm{~min}$ to prepare crude genomic DNA lysates. PCR amplification of $16 \mathrm{~S}$ rRNA genes from the crude lysates was performed using the 
universal primers $\mathrm{F} 1$ and $\mathrm{R} 13$ and products were sequenced as described previously (Kahng et al., 2010). The resulting $16 \mathrm{~S}$ rRNA gene sequences were analysed using the BLAST program (http://www.ncbi.nlm.nih.gov/BLAST/) in GenBank. From the BLAST analysis, a novel strain belonging to the genus Leuconostoc, designated strain $\mathrm{M}_{2}{ }^{\mathrm{T}}$, was selected for more phenotypic and phylogenetic analysis. The strain was routinely grown in MRS broth $(\mathrm{pH} 7.0)$ at $30{ }^{\circ} \mathrm{C}$ for 1 or 2 days without shaking and was stored at $-80{ }^{\circ} \mathrm{C}$ in MRS broth supplemented with $10 \%(\mathrm{v} / \mathrm{v})$ glycerol. Leuconostoc inhae KACC $12281^{\mathrm{T}}$, Leuconostoc kimchii $\mathrm{IH} 25^{\mathrm{T}}$, Leuconostoc gelidum KACC $12256^{\mathrm{T}}$, Leuconostoc holzapfelii DSM $21478^{\mathrm{T}}$ and Leuconostoc palmae DSM $21144^{\mathrm{T}}$ were used as reference strains for phenotypic characterization and DNA-DNA hybridization. Leuconostoc holzapfelii DSM $21478^{\mathrm{T}}$ and Leuconostoc palmae DSM $21144^{\mathrm{T}}$ were purchased from DSMZ (Germany). Leuconostoc kimchii $\mathrm{IH} 25^{\mathrm{T}}$ was a gift from Dr Kim (Kim et al., 2000) and Leuconostoc inhae KACC $12281^{\mathrm{T}}$, Leuconostoc gelidum KACC $12256^{\mathrm{T}}$, Leuconostoc gasicomitatum KACC $13854^{\mathrm{T}}$ and Leuconostoc mesenteroides subsp. mesenteroides KACC $12312^{\mathrm{T}}$ were gifts from KACC (Korea).

The 16S rRNA gene sequence (1361 nt) of strain $\mathrm{M} 2^{\mathrm{T}}$ was compared with $16 \mathrm{~S}$ rRNA gene sequences of related taxa using the EzTaxon nucleotide similarity search program (http://147.47.212.35:8080; Chun et al., 2007) and aligned by using the CLUSTAL W software program (Thompson et al., 1994). Phylogenetic trees using the neighbour-joining and maximum-parsimony algorithms were reconstructed by using the PHYLIP software (version 3.6, Felsenstein, 2002). The resulting tree topologies were evaluated using bootstrap analyses based on 1000 resampled datasets with the PHYLIP package. Maximum-likelihood analysis with bootstrap values was performed using RAxML-HPC BlackBox (version 7.2.6) of the Cyber-Infrastructure for Phylogenetic Research project (CIPRES, www.phylo.org; Stamatakis et al., 2005) at the San Diego Supercomputer Center.

To study the relatedness between strain $\mathrm{M}^{\mathrm{T}}$ and its neighbours in the genus Leuconostoc with a higher resolution than that provided by $16 \mathrm{~S}$ rRNA gene sequences, comparative sequence analysis of the recA gene was performed because multilocus sequencing of protein-encoding genes has become a common approach, especially for fine resolutions of close taxa (Konstantinidis \& Tiedje, 2005). The recA gene sequences of strain $\mathrm{M}^{\mathrm{T}}$ and Leuconostoc inhae KACC $12281^{\mathrm{T}}$ that were not available in public databases were amplified by using primers and PCR conditions as described by Dellaglio et al. (2005). The resulting PCR amplicons were purified and ligated into the pCR2.1 vector using a TOPO cloning kit (Invitrogen) according to the manufacturer's instructions and their inserts were sequenced by Macrogen (Korea). The resulting recA gene sequences were compared to available $r e c A$ gene sequences in GenBank. The compared $r e c A$ gene sequences were aligned using the CLUSTAL W software program, and a phylogenetic tree was reconstructed using the PROTDIST and neighbour modules available in the PHYLIP software (ver. 3.6).
DNA-DNA hybridization was carried out to evaluate the level of DNA relatedness between strain $\mathrm{M} 2^{\mathrm{T}}$ and Leuconostoc inhae KACC $12281^{\mathrm{T}}$, Leuconostoc gelidum KACC $12256^{\mathrm{T}}$ and Leuconostoc kimchii $\mathrm{IH} 25^{\mathrm{T}}$ as described previously (Lee et al., 2011). Briefly, extracted genomic DNA was fragmented with a HaeIII digestion and different amounts of the fragmented DNA were blotted onto Hybond-N + nylon membranes (Amersham Pharmacia Biotech) in three replicates after denaturation using $\mathrm{NaOH}$ solution and heating $\left(80^{\circ} \mathrm{C}\right)$. Each DNA $(4 \mu \mathrm{g})$ was used individually as a labelled DNA probe for cross-hybridization (Park et al., 2007). Random primed DNA labelling with digoxigenin (DIG)-dUTP and detection of hybrids by enzyme immunoassay on nylon membrane were performed using a DIG High Prime DNA Labelling kit (Roche Applied Science) according to the manufacturer's instructions. Hybridization signals were captured and analysed with Adobe Photoshop (ver. 7.0). The signals produced by hybridization of the probe to the homologous target DNA were taken to be $100 \%$ and signal intensities produced by the self-hybridization of a series of dilutions were used for the calculation of the levels of DNA relatedness between strain $\mathrm{M} 2^{\mathrm{T}}$ and each reference strain. The hybridization experiments were confirmed by cross-hybridizations.

Comparative analysis of 16S rRNA gene sequences showed that strain $\mathrm{M} 2^{\mathrm{T}}$ was most closely related to Leuconostoc inhae $\mathrm{IH}_{003^{\mathrm{T}}}$, Leuconostoc kimchii $\mathrm{IH} 25^{\mathrm{T}}$, Leuconostoc gasicomitatum LMG $18811^{\mathrm{T}}$, Leuconostoc gelidum DSM $5578^{\mathrm{T}}$, Leuconostoc palmae TMW2.694 ${ }^{\mathrm{T}}$ and Leuconostoc holzapfelii BFE $7000^{\mathrm{T}}$ with sequence similarities of $98.9 \%, 98.8 \%$, $98.8 \%, 98.7 \%, 98.5 \%$ and $98.2 \%$, respectively. Neighbourjoining phylogenetic analysis based on 16S rRNA gene sequences indicated that strain $\mathrm{M} 2^{\mathrm{T}}$ formed a phylogenetic lineage with Leuconostoc inhae KACC $12281^{\mathrm{T}}$ with a low bootstrap value ( $52 \%$ ) within the genus Leuconostoc (Fig. 1). On the other hand, phylogenetic analyses using the maximum-likelihood and maximum-parsimony algorithms showed that strain $\mathrm{M}^{\mathrm{T}}$ formed a phylogenetic lineage with Leuconostoc kimchii $\mathrm{IH} 25^{\mathrm{T}}$ with low bootstrap values, meaning that the phylogenetic topologies are not stable (Fig. S1, available in IJSEM Online). The phylogenetic trees based on the recA gene also revealed that strain $\mathrm{M}^{\mathrm{T}}$ formed a distinct phylogenetic lineage from other species of the genus Leuconostoc (Fig. 2). The DNA-DNA relatedness values between strain $\mathrm{M}^{\mathrm{T}}$ and Leuconostoc inhae KACC $12281^{\mathrm{T}}$, Leuconostoc kimchii $\mathrm{IH} 25^{\mathrm{T}}$, Leuconostoc gelidum KACC $12256^{\mathrm{T}}$, Leuconostoc gasicomitatum KACC $13854^{\mathrm{T}}$, Leuconostoc palmae DSM $21144^{\mathrm{T}}$ and Leuconostoc holzapfelii DSM $21478^{\mathrm{T}}$ were $13.8 \pm 3.2 \%, 14.3 \pm 3.4 \%, 9.9 \pm 1.0 \%, 13.2 \pm$ $0.8 \%, 22.4 \pm 4.9 \%$ and $16.2 \pm 4.6 \%$, respectively, which are clearly below the $70 \%$ threshold generally accepted for species delineation (Rosselló-Mora \& Amann, 2001).

Growth temperatures for strain $\mathrm{M}^{\mathrm{T}}$ were tested by growing the isolate on MRS agar at different temperatures $\left(0,4,20,25,30,35,37\right.$ and $\left.40{ }^{\circ} \mathrm{C}\right)$ for 3 days. Growth $\mathrm{pH}$ of strain $\mathrm{M} 2^{\mathrm{T}}$ was tested in MRS broth with different $\mathrm{pH}$ $\left(1.0-10.0\right.$ at $1.0 \mathrm{pH}$ unit intervals) at $30{ }^{\circ} \mathrm{C}$ for 3 days. The 


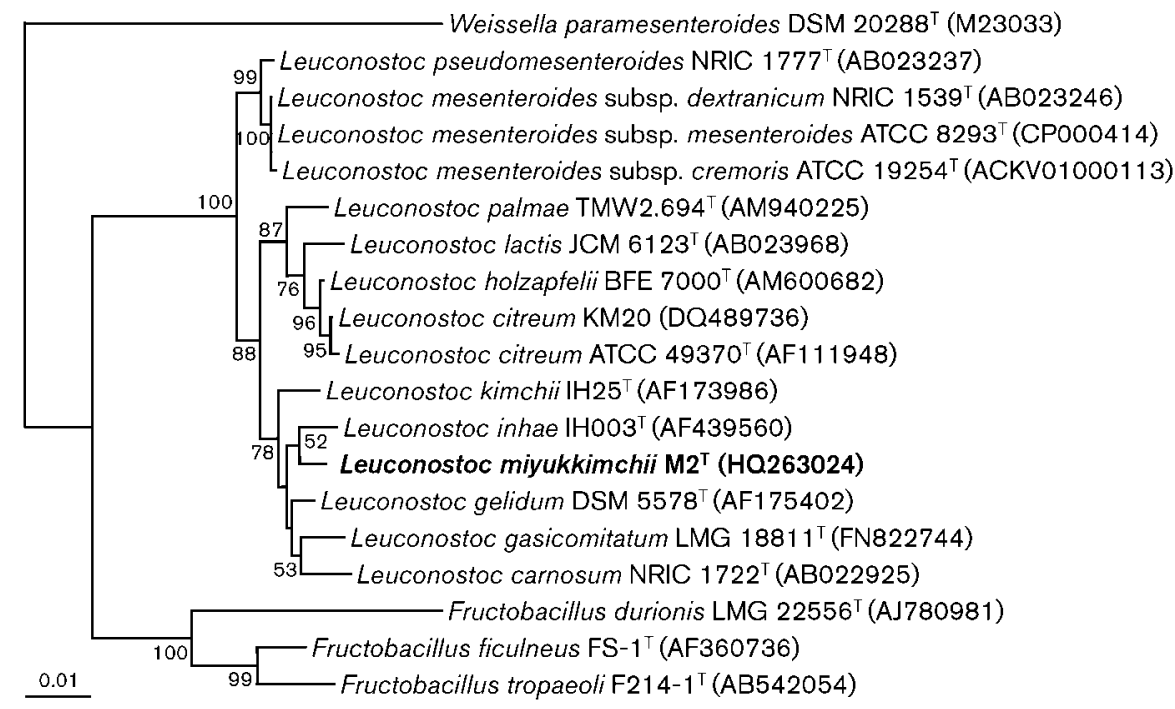

Fig. 1. Neighbour-joining tree based on $16 \mathrm{~S}$ rRNA gene sequences showing the phylogenetic relationships of strain $M 2^{\top}$ and related taxa. Bootstrap values are shown as percentages of 1000 replicates, when greater than $50 \%$. Weissella paramesenteroides DSM $20288^{\top}$ (M23033) was used as an outgroup. Bar, 0.01 changes per nucleotide position.

broth $\mathrm{pH}$ was adjusted prior to sterilization by the addition of $\mathrm{HCl}$ or $\mathrm{NaOH}$ and adjusted again after sterilization. After the growth of strain $\mathrm{M} 2^{\mathrm{T}}$, broth $\mathrm{pH}$ was measured again. Oxidase activity was tested by oxidation of $1 \%(\mathrm{w} / \mathrm{v})$ tetramethyl-p-phenylenediamine (Merck), and catalase activity was evaluated by the production of oxygen bubbles in $3 \%(\mathrm{v} / \mathrm{v})$ aqueous hydrogen peroxide solution (Smibert \& Krieg, 1994). Gas production from glucose was determined with a Durham tube in MRS broth. Gram staining was performed using the bioMérieux Gram stain kit according to the manufacturer's instructions. Cell morphology, motility and the presence of flagella were studied using phase-contrast microscopy (Axio Lab.A1; Carl Zeiss) and transmission electron microscopy (JEM1010; JEOL) with 2-day-old cells grown on MRS agar plates as described previously (Jeon et al., 2004). Requirement and tolerance of $\mathrm{NaCl}$ were determined in MRS broth supplemented with $0-10 \%$ (w/v, $1.0 \%$ intervals) $\mathrm{NaCl}$ for 5 days at $30{ }^{\circ} \mathrm{C}$. Carbohydrate fermentation profile was determined by using the API $50 \mathrm{CHL}$ system (bioMérieux) according to the manufacturer's instructions. Anaerobic growth was assessed on MRS agar plates under anaerobic (with $4-10 \% \mathrm{CO}_{2}$ ) conditions using the GasPak Plus system (BBL). The production of DL-lactic acid isomers from glucose by strain $\mathrm{M} 2^{\mathrm{T}}$ in MRS broth was determined with a DL-lactic acid enzyme test kit (R-biopharm) according to the manufacturer's protocol.

When tested on MRS agar plates, growth of strain $\mathrm{M} 2^{\mathrm{T}}$ was observed at temperatures between 4 and $35^{\circ} \mathrm{C}$, with an optimum growth temperature of $30{ }^{\circ} \mathrm{C}$; no growth was observed at $0{ }^{\circ} \mathrm{C}$ or $37{ }^{\circ} \mathrm{C}$. Growth of strain $\mathrm{M} 2{ }^{\mathrm{T}}$ in MRS

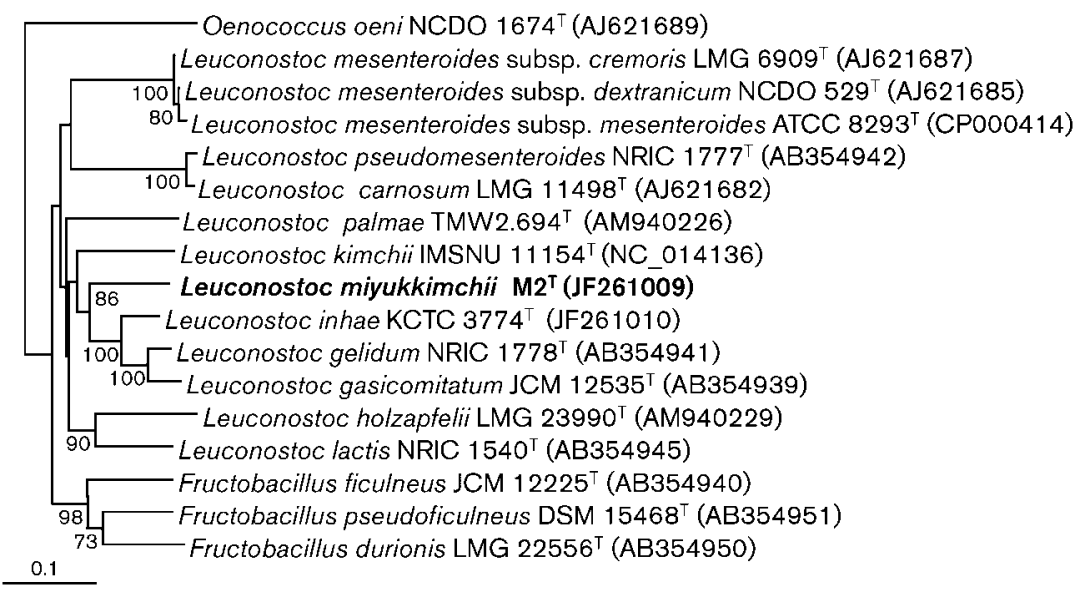

Fig. 2. Neighbour-joining tree based on recA gene sequences showing the phylogenetic relationships of strain $M 2^{\top}$ and related taxa. Oenococcus oeni NCDO $1674^{\top}$ (AJ621689) was used as an outgroup. Bar, 0.1 changes per nucleotide position. 
Table1. Differential phenotypic characteristics of strain $\mathrm{M}^{\top}$ and related species of the genus Leuconostoc

Strains; $1, \mathrm{M} 2^{\mathrm{T}}$ (this study); 2, Leuconostoc inhae KACC $12281^{\mathrm{T}}$ (Kim et al., 2003); 3, Leuconostoc gelidum KACC $12256^{\mathrm{T}}$ (Shaw \& Harding, 1989); 4, Leuconostoc kimchii IH25 ${ }^{\mathrm{T}}$ (Kim et al., 2000); 5 , Leuconostoc holzapfelii DSM 21478 ${ }^{\mathrm{T}}$ (De Bruyne et al., 2007); 6, Leuconostoc palmae DSM 21144 ${ }^{\mathrm{T}}$ (Ehrmann et al., 2009); 7, Leuconostoc mesenteroides subsp. mesenteroides KACC 12312 ${ }^{\mathrm{T}}$ (Garvie, 1979). All strains are positive for the following characteristics: acid production from D-glucose, D-fructose, D-mannose, $N$-acetylglucosamine and sucrose. All strains are negative for the following characteristics: motility, acid production from glycerol, erythritol, D-arabinose, L-xylose, D-adonitol, methyl $\beta$-D-xylopyranoside, L-sorbose, L-rhamnose, dulcitol, inositol, D-sorbitol, inulin, melezitose, glycogen, xylitol, D-lyxose, D-tagatose, fucose, D-arabitol and L-arabitol. +, Positive; -, negative; NA, not available.

\begin{tabular}{|c|c|c|c|c|c|c|c|}
\hline Characteristic & $1^{\star}$ & 2 & 3 & 4 & 5 & 6 & 7 \\
\hline Source & Brown algae kimchi & Kimchi & Chill-stored meats & Kimchi & Ethiopian coffee & Palm wine & $\mathrm{NA}$ \\
\hline Morphology & Ovoid & Spherical/lenticular & Spherical & Coccus & Ovoid/short rod & Coccus & Coccus/coccobacillus \\
\hline $\mathrm{NaCl}$ range for growth (\%) & $0-6$ & $0-3$ & $\mathrm{NA}$ & $0-7$ & Not at 6.5 & $0-3$ & $0-8^{*}$ \\
\hline Growth at $37^{\circ} \mathrm{C}$ & - & - & - & + & + & + & $+^{*}$ \\
\hline \multicolumn{8}{|c|}{ Acid production (API $50 \mathrm{CHL}$ ) from:* } \\
\hline Amygdalin & + & - & + & + & - & - & + \\
\hline L-Arabinose & - & + & - & + & + & - & + \\
\hline Aesculin/ferric citrate & + & - & + & + & + & + & + \\
\hline Galactose & - & - & + & + & + & - & + \\
\hline Gentiobiose & + & + & + & + & - & - & + \\
\hline Potassium gluconate & + & - & + & + & + & - & + \\
\hline Potassium 2-ketogluconate & + & - & + & + & - & - & - \\
\hline Potassium 5-ketogluconate & + & - & + & + & - & - & - \\
\hline Lactose & - & - & + & - & - & - & + \\
\hline Raffinose & - & - & + & - & + & - & + \\
\hline Ribose & + & + & + & + & - & - & + \\
\hline Salicin & + & - & + & + & - & - & + \\
\hline Starch & + & - & + & - & - & - & - \\
\hline Trehalose & + & + & + & + & + & - & + \\
\hline Turanose & + & - & + & + & + & - & + \\
\hline D-Xylose & + & - & + & - & - & - & + \\
\hline DNA G $+C$ content $(\mathrm{mol} \%)$ & 42.5 & $39.9 \pm 0.5$ & 37 & 37 & 43.5 & 36.4 & 38.5 \\
\hline
\end{tabular}

${ }^{*}$ Results from this study. 
broth occurred at an initial $\mathrm{pH}$ of 5.0-9.0; final $\mathrm{pH}$ after growth of strain $\mathrm{M}^{\mathrm{T}}$ was around $\mathrm{pH}$ 4.3. Strain $\mathrm{M} 2^{\mathrm{T}}$ grew in MRS broth supplemented with $0-6.0 \%(\mathrm{w} / \mathrm{v})$ $\mathrm{NaCl}$; optimal growth occurred without the addition of $\mathrm{NaCl}$. Gas was produced from glucose. Bacterial cells were Gram-staining-positive, facultatively anaerobic ovoid types that usually occurred in groups with a size of 0.5$0.7 \times 0.7-0.9 \mu \mathrm{m}$ (Fig. S2). Phenotypic features of strain $\mathrm{M} 2^{\mathrm{T}}$ are presented in Table 1 and in the description of the novel species. Some of them are in accordance with characteristics of members of the genus Leuconostoc, whereas others allow the differentiation of strain $\mathrm{M} 2{ }^{\mathrm{T}}$ from closely related species of the genus Leuconostoc (Table 1).

The DNA G $+\mathrm{C}$ content of strain $\mathrm{M} 2^{\mathrm{T}}$ was determined by the fluorometric method (Gonzalez \& Saiz-Jimenez, 2002) by using SYBR Green I and a real-time PCR thermocycler (Bio-Rad). The DNA G $+\mathrm{C}$ content of strain $\mathrm{M}^{\mathrm{T}}$ was $42.5 \mathrm{~mol} \%$, which was within the range of other species of the genus Leuconostoc (38-44 mol\%; De Bruyne et al., 2007). Therefore, on the basis of the physiological, biochemical and phylogenetic properties described above, strain $\mathrm{M}^{\mathrm{T}}$ represents a novel species in the genus Leuconostoc, for which the name Leuconostoc miyukkimchii sp. nov. is proposed.

\section{Description of Leuconostoc miyukkimchii sp. nov.}

Leuconostoc miyukkimchii [mi.yuk.kim'chi.i. N.L. n. miyukkimchium miyukkimchi, a regional kimchi made of a brown algae (Undaria pinnatifida); N.L. gen. n. miyukkimchii of miyukkimchi].

Cells are Gram-staining-positive, facultatively anaerobic, non-spore-forming ovoid types without motility. Colonies on MRS agar are creamy white, convex and circular with smooth margins. Growth occurs at $4-35^{\circ} \mathrm{C}$ (optimum, $30{ }^{\circ} \mathrm{C}$ ) and at $\mathrm{pH} 5-9$. Negative for oxidase and catalase. Grows in MRS broth supplemented with $0-6.0 \%(\mathrm{w} / \mathrm{v})$ $\mathrm{NaCl}$, but not $7 \% \mathrm{NaCl}$ or higher concentrations. Heterofermentative; gas and DL-lactic acid $(78.9: 21.1)$ are produced from glucose. Acid is produced from starch, amygdalin, arbutin, cellobiose, aesculin, D-fructose, gentiobiose, D-glucose, maltose, D-mannitol, D-mannose, methyl $\alpha$-D-glucopyranoside, $N$-acetylglucosamine, potassium 2ketogluconate, potassium 5-ketogluconate, potassium gluconate, D-ribose, salicin, sucrose, trehalose, turanose and D-xylose. Acid is not produced from D-adonitol, arabinose, arabitol, dulcitol, erythritol, fucose, D-galactose, glycerol, glycogen, inositol, inulin, lactose, D-lyxose, melezitose, melibiose, methyl $\alpha$-D-mannopyranoside, methyl $\beta$-D-xylopyranoside, raffinose, L-rhamnose, D-sorbitol, L-sorbose, Dtagatose or xylitol. The DNA G $+\mathrm{C}$ content of the type strain is $42.5 \mathrm{~mol} \%$.

The type strain is $\mathrm{M}^{\mathrm{T}}\left(=\mathrm{KACC} 15353^{\mathrm{T}}=\mathrm{JCM} 17445^{\mathrm{T}}\right)$, isolated from Korean fermented brown algae (Undaria pinnatifida) kimchi.

\section{Acknowledgements}

These efforts were supported by the Technology Development Program for Agriculture and Forestry (TDPAF) of the Ministry for Agriculture, Forestry and Fisheries and the Next-Generation BioGreen 21 Program (no. SSAC2011-PJ008220), Rural Development Administration, Republic of Korea.

\section{References}

Chambel, L., Chelo, I. M., Zé-Zé, L., Pedro, L. G., Santos, M. A. \& Tenreiro, R. (2006). Leuconostoc pseudoficulneum sp. nov., isolated from a ripe fig. Int J Syst Evol Microbiol 56, 1375-1381.

Cheigh, H. S., Park, K. Y. \& Lee, C. Y. (1994). Biochemical, microbiological, and nutritional aspects of kimchi (Korean fermented vegetable products). Crit Rev Food Sci Nutr 34, 175-203.

Choi, H. J., Cheigh, C. I., Kim, S. B., Lee, J. C., Lee, D. W., Choi, S. W., Park, J. M. \& Pyun, Y. R. (2002). Weissella kimchii sp. nov., a novel lactic acid bacterium from kimchi. Int J Syst Evol Microbiol 52, 507-511.

Chun, J., Lee, J. H., Jung, Y., Kim, M., Kim, S., Kim, B. K. \& Lim, Y. W. (2007). EzTaxon: a web-based tool for the identification of prokaryotes based on $16 \mathrm{~S}$ ribosomal RNA gene sequences. Int J Syst Evol Microbiol 57, 2259-2261.

De Bruyne, K., Schillinger, U., Caroline, L., Boehringer, B., Cleenwerck, I., Vancanneyt, M., De Vuyst, L., Franz, C. M. A. P. \& Vandamme, P. (2007). Leuconostoc holzapfelii sp. nov., isolated from Ethiopian coffee fermentation and assessment of sequence analysis of housekeeping genes for delineation of Leuconostoc species. Int J Syst Evol Microbiol 57, 2952-2959.

Dellaglio, F., Felis, G. E., Castioni, A., Torriani, S. \& Germond, J. E. (2005). Lactobacillus delbrueckii subsp. indicus subsp. nov., isolated from Indian dairy products. Int J Syst Evol Microbiol 55, 401-404.

Ehrmann, M. A., Freiding, S. \& Vogel, R. F. (2009). Leuconostoc palmae sp. nov., a novel lactic acid bacterium isolated from palm wine. Int $J$ Syst Evol Microbiol 59, 943-947.

Felsenstein, J. (2002). PHYLIP (phylogeny inference package), version 3.6a, distributed by the author. Department of Genome Sciences, University of Washington, Seattle, USA.

Garvie, E. I. (1979). Proposal of the neotype strains for Leuconostoc mesenteroides (Tsenkovskii) van Tieghem, Leuconostoc dextranicum (Beijerinck) Hucker and Pederson, and Leuconostoc cremoris (Knudsen and Sørensen) Garvie. Int J Syst Bacteriol 29, 149-151.

Gonzalez, J. M. \& Saiz-Jimenez, C. (2002). A fluorimetric method for the estimation of $\mathrm{G}+\mathrm{C}$ mol\% content in microorganisms by thermal denaturation temperature. Environ Microbiol 4, 770-773.

Jeon, C. O., Park, W., Ghiorse, W. C. \& Madsen, E. L. (2004). Polaromonas naphthalenivorans sp. nov., a naphthalene-degrading bacterium from naphthalene-contaminated sediment. Int J Syst Evol Microbiol 54, 93-97.

Jung, J. Y., Lee, S. H., Kim, J. M., Park, M. S., Bae, J.-W., Hahn, Y., Madsen, E. L. \& Jeon, C. O. (2011). Metagenomic analysis of kimchi, a traditional Korean fermented food. Appl Environ Microbiol 77, 22642274.

Kahng, H. Y., Lee, S. S., Kim, J. M., Jung, J. Y., Lee, M. Y., Park, W. \& Jeon, C. O. (2010). Muriicola jejuensis gen. nov., sp. nov., isolated from seawater. Int J Syst Evol Microbiol 60, 1644-1648.

Kim, J., Chun, J. \& Han, H.-U. (2000). Leuconostoc kimchii sp. nov., a new species from kimchi. Int J Syst Evol Microbiol 50, 1915-1919.

Kim, B., Lee, J., Jang, J., Kim, J. \& Han, H. G. (2003). Leuconostoc inhae sp. nov., a lactic acid bacterium isolated from kimchi. Int J Syst Evol Microbiol 53, 1123-1126. 
Kim, J. M., Le, N. T., Chung, B. S., Park, J. H., Bae, J.-W., Madsen, E. L. \& Jeon, C. O. (2008). Influence of soil components on the biodegradation of benzene, toluene, ethylbenzene, and $o^{-}, \mathrm{m}^{-}$, and $p$-xylenes by the newly isolated bacterium Pseudoxanthomonas spadix BD-a59. Appl Environ Microbiol 74, 7313-7320.

Konstantinidis, K. T. \& Tiedje, J. M. (2005). Towards a genome-based taxonomy for prokaryotes. J Bacteriol 187, 6258-6264.

Lee, J. S., Chun, C. O., Jung, M.-C., Kim, W.-S., Kim, H. J., Hector, M., Kim, S. B., Park, C. S., Ahn, J.-S. \& other authors (1997). Classification of isolates originating from Kimchi using carbon source utilization patterns. J Microbiol Biotechol 7, 68-74.

Lee, J.-S., Lee, K. C., Ahn, J.-S., Mheen, T.-I., Pyun, Y.-R. \& Park, Y.-H. (2002). Weissella koreensis sp. nov., isolated from kimchi. Int J Syst Evol Microbiol 52, 1257-1261.

Lee, S. H., Shim, J. K., Kim, J. M., Choi, H. K. \& Jeon, C. O. (2011). Henriciella litoralis sp. nov., isolated from a tidal flat, transfer of Maribaculum marinum Lai et al. 2009 to the genus Henriciella as Henriciella aquimarina nom. nov. and emended description of the genus Henriciella. Int J Syst Evol Microbiol 61, 722-727.

Mheen, T. I. \& Kwon, T. W. (1984). Effect of temperature and salt concentration of Kimchi fermentation. Kor J Food Sci Technol 16, 443-450.

Park, M., Ryu, S. H., Vu, T. H., Ro, H. S., Yun, P. Y. \& Jeon, C. O. (2007). Flavobacterium defluvii sp. nov., isolated from activated sludge. Int J Syst Evol Microbiol 57, 233-237.
Rosselló-Mora, R. \& Amann, R. (2001). The species concept for prokaryotes. FEMS Microbiol Rev 25, 39-67.

Shaw, B. G. \& Harding, C. D. (1989). Leuconostoc gelidum sp. nov. and Leuconostoc carnosum sp. nov. from chill-stored meats. Int J Syst Bacteriol 39, 217-223.

Smibert, R. M. \& Krieg, N. R. (1994). Phenotypic characterization. In Methods for General and Molecular Bacteriology, pp. 607-654. Edited by P. Gerhardt, R. G. E. Murray, W. A. Wood \& N. R. Krieg. Washington, DC: American Society for Microbiology.

So, M. H. \& Kim, Y. B. (1995). Identification of psychrophilic lactic acid bacteria isolated from kimchi. Kor J Food Sci Technol 27, 495-505.

Song, Y. O. (2004). The functional properties of kimchi for the health benefits. J Food Sci Nutri 9, 27-33.

Stamatakis, A., Ott, M. \& Ludwig, T. (2005). RAxML-OMP: An efficient program for phylogenetic inference on SMPs. In Proceedings of the 8th International Conference on Parallel Computing Technologies (PaCT2005), Lecture Notes in Computer Science, 3506, 288-302. Springer.

Thompson, J. D., Higgins, D. G. \& Gibson, T. J. (1994). CLUSTAL W: improving the sensitivity of progressive multiple sequence alignment through sequence weighting, position-specific gap penalties and weight matrix choice. Nucleic Acids Res 22, 4673-4680.

Yoon, J. H., Kang, S. S., Mheen, T. I., Ahn, J. S., Lee, H. J., Kim, T. K., Park, C. S., Kho, Y. H., Kang, K. H. \& Park, Y. H. (2000). Lactobacillus kimchii sp. nov., a new species from kimchi. Int J Syst Evol Microbiol 50, 1789-1795. 